State ownership and innovation: the relative merits of local and central state judged by innovation performance

First author (corresponding author)

Dr Jing Cai

Senior lecturer in Management Studies

University of Aberdeen Business School

McRoberts Building

AB24 5UA

jing.cai@abdn.ac.uk

$+44(0) 1224272394$

Second author

Dr Radomir Tylecote

Senior Research Analyst

Institute of Economic Affairs

2 Lord North Street

SW1P 3LB

rado.tylecote@gmail.com

+44(0) 2077998917

Third author

Professor Ignacio Canales

Management studies

University of Aberdeen Business School

McRoberts Building

AB24 5UA

ignacio.canales@abdn.ac.uk

$+44(0) 1224273236$ 
Fourth author

Dr Takahiko Kiso

Lecturer in Economics

University of Aberdeen Business School

Edward Wright Building

AB24 3QY

tkiso@abdn.ac.uk

+44(0)1224273423 


\title{
State ownership and innovation: the relative merits of local and central state judged by innovation performance
}

\begin{abstract}
This paper compares the innovation performance of state-owned firms owned by different levels of government, with that of privately-owned firms. Analysis of a 116-firm panel dataset for the Chinese solar photovoltaic industry from 1999-2015 suggests that government's financial support increases the quantity of innovation outputs. However, the efficiency in utilising the financial resources is determined by the effectiveness of agency relationships. Applying agency theory to the Chinese politico-economic context indicates that innovation quality depends on length and complexity of agency chains, engagement of monitors, and the tenure of managers. By using forward citations and proportion of patents in active use, two measures of innovation quality that are more valid and reliable than patent counts, our study finds that municipallyowned firms are superior in terms of innovation productivity to those under central ownership, and comparable to private firms.
\end{abstract}

Key words: agency theory, governance of innovation, level of state ownership, innovation performance, solar photovoltaic industry. 


\section{Introduction}

A growing body of research has examined innovation performance by comparing state-owned (SOE) and privately owned (POE) enterprises, as ownership type is considered as a key factor that affects firms' innovation (Choi et al., 2011; Connelly et al., 2010). Whilst early studies assumed that POEs outperformed SOEs (Shleifer and Vishny, 1986), recent studies have suggested the opposite regarding innovation (Choi et al., 2011; Mutlu et al. 2018). These inconclusive results have encouraged researchers to take a more nuanced approach by differentiating categories of state ownership (Li et al., 2017; Zhou et al., 2017). One such approach is to look at a mixed ownership structure where the state owns just a proportion of the shares. Such studies show that the lower the proportion of state ownership in SOEs, the higher the innovation (Boeing et al., 2016; Poczter, 2016; Zhou et al., 2017). Another approach, albeit understudied, is to compare ownership by local government with that by the central state. Li et al. (2017) for example find that central state ownership leads to better new product sales. Their argument is that the central state, as a shareholder, has striking advantages in getting access to financial resources. On the other hand, Zhou et al. (2017) argue that state ownership, as a whole, is less efficient in using financial resources to generate innovation. This inefficiency may well vary between levels of government. The present study situates 'local versus central' in a broader context: how is innovation performance affected by financial resources and their utilisation? In consequence, the research questions guiding this study are: how does innovation performance vary across levels of state ownership in terms of access to and utilisation of financial resources? And how does the performance of each level of state ownership compare with that of whollyowned POEs? 
In order to systematically answer these two questions, this paper draws on agency theory (Connelly et al. 2010; Jensen and Meckling, 1976) and institutional theory (DiMaggio \& Powell, 1991; Godfrey, 2014). Research on SOE performance has mainly centred on three theories: transaction cost economics, institutional theory and agency theory. Transaction cost assumes organisations are formed on the basis of markets and hierarchies (Williamson, 1975). SOEs are in general weak in the aspect of market. Research therefore suggests that government agencies should behave in a more business-like manner (André, 2010). In addition, this stream of research largely advocates private firms instead of services provided by SOEs (Pache \& Santos, 2013). Such proposition does not convey strong policy implication to governments who still value highly the strategic importance of SOEs in their industries or economies.

Institutional theory sees SOEs as products of institutional environment (Godfrey, 2014). SOEs' performance is shaped by institutions such as government financial incentives (Guan and Yam, 2015), subsidies (Yu et. al. 2016), logics (Zhou et al., 2017), and rules and norms (Scott, 2014). This perspective highlights the significance of institutional setting in which SOEs operate. However, it does not provide much insight into the efficiency aspect of SOE performance. Classical agency theory addresses efficiency by focusing on the relationship between principals/owners and agents/managers (Connelly et al. 2010; Jensen and Meckling, 1976). It assumes that there are conflicts between them (Eisenhardt, 1989). Agents are self-interest seekers (Jensen and Meckling, 1976). To achieve efficiency, the principals need to devise appropriate monitoring and incentive mechanisms to align agents' interests to those of the principals. However, this classic view tends to be under-contextualised (Aguilera et al., 2008) in implicitly making assumptions about contextual factors, such as the state staying in the background or easily enforceable contracts, which do not necessarily hold for developing economies. 
This paper aims to make one major and two minor contributions. First, theoretically it contextualises agency theory with institutional theory in order to have a better understanding of SOE innovation performance in terms of financial resources and utilisation. More specifically, within the broad sphere of institutional theory, we use the approach of National System of Innovation (NSI) to contextualise the agency theory. NSIs highlight country-specific institutional factors, including the powers and policies of government, to explain national innovation performance (Freeman, 1987). Governments in emerging economies deploy various intervention instruments to cultivate innovation. Using a combined theoretical approach helps reconcile the inconclusive findings regarding SOEs innovation performance (Choi et al., 2011), which may only draw on one theoretical perspective. It also allows us to differentiate the agency situation of SOEs owned/controlled by different levels of government, with important implications for policy.

Our second contribution is closely connected to the first.. Our focus on emerging economies leads us to identify specific requirements of innovation governance there, distinct from those in advanced economies, which are familiar in extant literature (Aghion et al. 2013, Schmid et al.2014): The key factor in most of the 'advanced' literature is the riskiness of innovation: we argue that for firms in emerging economies this is less important than the long time to pay-off. Accordingly for such firms long tenure of top managers is advantageous.

Finally, this paper also contributes to the measurement of innovation performance in emerging economies with 'developmental states'. We agree with current best practice in judging innovation performance in terms of patent data (Boeing et. al., 2016) but we argue that patent data has to be treated with suspicion in SOEs in such states because it may be gamed manipulated by agents in order to impress monitors. We propose, and use, two dimensions of patent data which are not amenable to gaming. An alternative measure of innovation is 
'proportion of new product sales in total sales'. Research that claims to find strong innovative performance of SOEs usually relies on this measure (e.g. Li et al., 2017)., We show the deficiencies of NPS as a measure of innovation

We constructed a panel dataset of 69 SOEs (wholly or majority state-owned, henceforth 'SOEs') and 47 POEs (wholly owned by domestic private shareholders, henceforth 'POEs') consisting of information at firm level (from 1999 to 2015) regarding patents, shareholding, and R\&D.

In the next section, we apply agency theory to innovation in state-owned firms in emerging economies, and then use the Chinese national system of innovation to fully contextualize agency theory and generate hypotheses. The following sections outline the research methods, explain the panel dataset, and present study findings. Finally, we discuss the research results and provide conclusions.

\section{Theory, institutional context, and hypotheses}

\subsection{Agency theory and innovation}

An agency relationship is classically defined as one where one person, the principal, hires another individual, an agent, to carry out a task on behalf of the principal. In consequence, information asymmetry occurs, that is, agents (managers) know more than principals (shareholders, investors) about their actions and their consequences. The general challenge under these circumstances is how to motivate the agent to act as the principal would wish if fully informed, which would typically be to maximise profit (Eisenhardt, 1989). Strikingly, our study does not deal with classically-defined principal-agent relationships, because (as we shall show) they are rare in Chinese industry in general and in the solar PV industry in particular. In 
privately-owned enterprises (POEs) generally, the original founders remain principals, and also remain top managers; so who are the agents? In state-owned enterprises (SOEs) there are certainly agents - top managers of the enterprise. But who are the principals?

The POE case is familiar in Western agency literature, which has identified types of family firms in which there are indeed no agents: instead there are two or more categories of principal: typically insiders (family members who are top managers with shares) and outsiders (family and non-family members who are minority shareholders) (Bergloef, 1997 and Schmid et al., 2014). Insiders normally have much more information than outsiders. The larger the proportion of the firm's capital held by insiders, the less the distortion of behaviour.

The SOE case is less familiar, but the logic is clear: those officials who hire, fire and (hopefully) monitor management are acting as principals. It may be, in a large country, that these officials are themselves hired/fired/monitored by more senior officials. It is then the most senior officials in the hierarchy who most resemble ultimate principals (Liu and Tylecote 2009). Thus here too the insights of agency theory are relevant, because there is one party (or more) with ultimate power but lacking information, and another with information but ultimately without power.

In this study, we apply the insights of agency theory to the specific issue of innovation, which is in advanced economies a form of investment with two key characteristics. First, it tends to be risky (Schivardi and Schneider 2008, Minetti et al 2015 Aghion et al., 2013) and so any risk-aversion will work against it. Indeed even principals who are not risk-averse may appear to be, since if the outcome is poor for stochastic reasons, they may mistakenly take this as a signal of managerial incompetence (Aghion et al. 2013). Second, it tends to have high up-front costs and to take considerable time to pay off (Hall 2005) while being granular and informationally 
opaque (Rajan and Zingales 2001), so that there are no good interim signals of performance. Consequently principals (including 'outsider principals' in family businesses) may display shorttermism towards innovation - preference for projects with a quick financial pay-off - even if they have normal time preferences.

We note that the argument so far relates to advanced economies in which 'innovation' can be taken as 'introduction of products and processes which are, more or less, new to the world'. Emerging economies such as China was in our period, are different: the 'latecomer firms' (Mathews 2002) which lead the domestic industry will be technological followers making incremental improvements at most. The governance of such innovation is substantially different. Both technological and market uncertainties will have been largely removed by the experience of advanced firms. Risk aversion therefore matters rather less. Short termism however may well matter just as much to a technological follower, which has a great deal of learning to do and may need to take time to 'invent round' a 'patent blockade' constructed by advanced firms (Xiao et al 2013).

The commonalities and the differences in the nature of innovation between advanced and emerging economies carry through to agency analysis. In both types there is a short-termism problem. The remedy for short-termism valid only in emerging economies is to align incentives by giving top managers a long tenure of their posts. The longer the remaining tenure expected by managers when an innovation decision is made, the more likely they will see pay-off as within their time horizon, and invest in innovation accordingly. In advanced economies such alignment of incentives might be bought at too high a price - opposition by entrenched top managers to radical or disruptive innovation. Latecomer firms' managers may also dislike radical change, but they can wait until it has been proven necessary. 
The remedy valid in both types of innovation is to reduce asymmetry of information between principals and agents through monitoring by principals or their representatives. Monitors need to engage with managers, and in so doing learn about their actions and assess their immediate outcomes. Thus Shleifer and Vishny (1986), found higher performance in firms with concentrated shareholdings: strategic blockholders are needed with a strong incentive to engage in depth. What is the alternative to incurring the cost of engagement? 'Dis-engaged' principals may resort to easily-available data as an indicator of managerial performance: the most easily available is standard financial data as published for listed firms, but this is very much a lagging indicator of innovation, which will inevitably encourage short-termism. More of a leading indicator is patent data, to be discussed below. Risk is not absent in an emerging economy. A major justification for the creation of firms with fragmented shareholdings is of course to spread risk. POEs which are unlisted fail to do this and they, or their dominant shareholders, can be expected to show risk aversion accordingly.

\subsection{The evolution of the Chinese NSI}

Freeman (1987:1) defined an NSI as a "network of institutions in the public and private sectors whose activities and interactions initiate, import, modify, and diffuse new technologies". To apply the agency theory presented above, we need to understand the Chinese NSI, beginning with the structure of the Chinese state. While ultimate power lies entirely at the centre, the size of the country means that much is delegated to lower levels of government - provinces, cities, districts and below. In particular, most state enterprises are owned and controlled by 'sub-central' levels of government (Sun and Liu, 2010). We categorise the levels of government, in descending order, as (1) centre (2) 'super-municipal': four great cities, Beijing, Shanghai, Tianjin 
and Chongqing, which have the status of provinces; (3) Provinces; (4) Municipal (cities and townships). In 1994 the relationship between central and local government was modified to give local government more discretion and more incentive to produce economic growth - by letting them keep a share of the proceeds (Cull et al., 2017).

After China joined the WTO, in 2001-5, there was a heavy emphasis on selective support, for favoured higher-technology firms by buying from them (preferential public procurement), lending to them cheaply (financial resources, land), and/or subsidizing their research and development or even giving them forewarning of changes in policy (Inoue et al, 2013). In 2000, total government spending on science and technology (S\&T) was RMB57.6 billion (0.46\% of GDP), while by 2012 it was RMB560 billion (1.08\% of GDP) (STC, 2014). The 2012 figure included heavy spending on certain Strategic and Emerging Industries of which the first in importance was Clean Energy (Fuller, 2016; State Council, 2010). This included Solar PV. The main sources of subsidy for firms' R\&D are the 863 Program (with RMB 8.1 bn spent through firms in 2012) and the Key Technologies Program (RMB5.66bn in 2012) (China Statistical Yearbook on Science and Technology, 2013). POEs can get subsidies for their R\&D, but SOEs in general get more (Boeing et. al., 2016). This applies also to cheap loans (Cull et al., 2015), and to land procurements (Deng et al., 2009). Local government can subsidize from the Torch Program (RMB1.75bn provided by local government in 2012) and offer cheap loans from stateowned banks. However, there is a clear hierarchy of prestige and power among SOEs, within which central SOEs are at the top (Li et al., 2017), and they have the best access to subsidies and to other funding.

\subsection{Agency theory applied to China}


On the one hand, classical agency theory has limited relevance to POEs in China. The large majority of POEs are still managed by their founders, or their families (Deng et al., 2013; and we found founder management to be almost universal in our sample), so any 'agency conflict' is between two sorts of principals - dominant, usually majority shareholders (insider principals), and minority shareholders/fixed interest investors (outsider principals). Here innovation may be reduced or distorted in two main ways. First, the dominant shareholders may have committed so much of their assets to the firm that they display strong risk aversion. Second, the other investors are unable to penetrate the information opacity and therefore show short-termism towards proposed innovation. For SOEs, one can argue that they need the equivalent of a 'blockholder' as in Shleifer and Vishny (1986): some state organization which has power over the SOE and the incentive to use it, and to engage and develop industrial expertise. We do not find this in Chinese central SOEs. In principle, three government bodies jointly oversee each central SOE: the relevant Ministry, the State-owned Assets Supervision and Administration Commission of the State Council (SASAC) and the Organization Department of the Communist Party. In 2017, there were 102 central SOEs, complex corporate groups, with many subsidiaries, operating across more than 50 industries. SASAC does not have the power to appoint or remove top SOE executives (Wang et al., 2012). These are senior officials and as such their appointments, and their careers, are controlled primarily by the Organization Department of the Party - which does not oversee their firm as such. It is common for a central SOE top manager to serve for a short period, perhaps three years, and then move 'up' to a political posting (Brodsgaard, 2012). As for the relevant Ministries, successive reforms have reduced their staff and their status, making them unable in effect to give orders to a central SOE (Brodsgaard 2012). 
The central SOEs are thus Small Kingdoms (Brodsgaard, 2012) which are monitored very lightly and get to keep most of their profits. A top manager who has moved up to a political position may well thereby get opportunities to protect the interests of his central SOE, through (for example) state subsidies and preferential public purchasing of their products; also to help his colleagues there to further their careers inside and outside the firm. There is no outsider who would be in a position to interrogate individuals or the firm as such on its performance with regard to innovation. The SOE merely has to give the general impression that they are functioning parts of the developmental state's innovation drive.

The agency situation seems still more complex for lower-level SOEs, since both the Organization Department and SASAC have municipal branches, which report to provincial branches, which in turn report to the center. There are therefore one or two extra links in the agency chain, which should make information asymmetry still worse. However, in practice the situation at lower levels, particularly municipal, is simpler. The third monitoring organization, the relevant Ministry, has no local presence, and tends not to supervise local, particularly municipal, governments closely (Lu and Feng 2004). And as pointed out above, local government has had wide discretion of action since the mid-1990s, as long as it performs well against simple measures of income per head, tax revenue, and employment (Chung, 2000).

In consequence, a municipal party secretary may well lead a cohesive group, including the local heads of the Organization Department and SASAC, which monitors and even establishes municipal SOEs and acts in effect as sole principal. Such a group can meet the main criteria for effective monitoring, that is, power over the firm, and importance of the firm to the monitors. A successful SOE will contribute to the standard metrics of income per head and employment by which local officials are judged, and its reputation may catch the ear of Beijing (Fuller, 2016). 
This encourages engagement.. It can also lead to long job tenure for top managers - over 20 years for the successful Ma Shichun in Guizhou Tyre (Liu and Tylecote, 2009). One head of a municipal SASAC stated:

“... we (local government) can provide a stable institutional infrastructure for their (local businesses') development. [A] good investment principal does not necessarily have to operate the business; rather, we can receive fruitful results through effective governance and active guidance.” (Qian, 2002, 4)

Moving down the political hierarchy from central to municipal government is equivalent to transferring state shareholdings from 'social-political orientated' to 'market-orientated' organization. (Cull et al., 2017).

State banks making loans and state agencies granting subsidies have a sort of principalagent relationship with the managers of the firms they finance. The process of granting of loans and subsidies displays information asymmetry similar to the corporate governance process: managers know how they spend the Science \& Technology funding they receive, and their government funders can often only guess. Thus, the minister of Science and Technology, estimated in October 2013 that only 40 percent of S\&T subsidy funds were actually spent on the projects for which they were granted (Fuller, 2016). From the discussion above, we infer that central SOEs are likely to do much of this misallocation.

2.4 The double role of measures of innovation in governance and in research method Researchers face exceptional difficulties in measuring innovation in SOEs in a developmental state, because the measures they use are also used by government, and top managers therefore 'game' them. Patents may be used to protect the results of invention and the foundations of 
innovation, and as such they are lead indicators of innovation (Pisano and Teece, 2007). This offers disengaged monitors a relatively cheap and easy way of reducing asymmetry of innovation; but management can game this by taking out patents on worthless inventions.. Similarly, new product sales may be an indicator of commercial achievement of innovation. On the other hand a well-financed SOE in an emerging economy can produce high 'NPS' by buying in technology from advanced firms, without itself innovating. Consequently, patents and new product sales seem to offer disengaged monitors a relatively cheap and easy way of reducing asymmetry of information. Chinese patent examiners are paid more if they approve more patents, and generosity of incentives for patent-filing may make it "worthwhile for companies and individuals to patent even worthless ideas" (The Economist, October 2010). The traditional measure, patent numbers, is thus highly unreliable. Currently the Chinese State Intellectual Property Office (SIPO) allows three forms of patent to be filed: invention patents, utility models, and designs. We shall call the latter two categories 'non-invention patents'. SIPO appears to award them to whomever fills in the forms correctly (Fuller 2016). According to the World Intellectual Property Office (WIPO), China became the world's leading patent filer in 2011. In 2014 about 60\% of patent filings fell in the "non-invention" classes (36.8\% Utility and 23.9\% Design, http://www.sipo.gov.cn/twzb/2014fmzlsqqkfbh/). Summing up: one Beijing-based IP lawyer stated: "the government targets deprive firms of an incentive to really innovate" (interview data, September, 2012). In this research, numbers of non-invention patents are used as an indicator not of innovating but of gaming. Even invention patent numbers are not a reliable indicator of innovativeness. Some indicator of inventive quality is needed, and has been found by earlier researchers in forward citations (OECD 2009). A patent which has been cited by five successful subsequent patent applications, for example, scores five. (Self citation is of course excluded; we 
also exclude domestic citation.) One which has not been thus cited at all scores zero. Clearly gaming forward citations would be much more difficult than simply getting a patent.

Another indicator of patent value is that the patent is kept active by payment to the awarding office, in order for the technology to be used either in firms' own new products/processes, or licensed out. The average years of activity are low in China, by international standards, which tends to indicate that this measure is gamed less than the original filing for patents (Qiao and Shen, 2017; Xinhua News, 2017).

\subsection{Hypotheses}

In sum, we have argued that firms owned by lower levels of government in China have more effective monitoring, and better-aligned incentives, and thus more effective corporate governance than central SOEs, particularly from the point of view of innovation. As to POEs, these are predominantly owner-managed, and so their main agency problem is risk aversion: among outsider principals because of their lack of information, and insider principals because much of their wealth is committed to the firm. They are at the same time bottom in terms of availability of state funding - while central SOEs come top. We now proceed to develop hypotheses.

We begin with the key input to innovation: research and development (R\&D). We have seen that central SOEs have a very low opportunity cost of capital, and the need to show some evidence that they are innovating. Municipal SOEs are at the other end of the SOE range, from these points of view. And at the other extreme, private firms (POEs) have the highest opportunity cost of capital and least need to show that they are innovating, since the most important principal has most knowledge. This yields Hypothesis 1: 
Hla: The higher the level of government with a dominant shareholding, the higher the rate of spend on $R \& D$ relative to turnover ( $R \& D$ intensity).

HIb: Municipal SOEs have higher R\&D intensity than POEs.

We now turn to outputs from innovation. We begin with the output most easily gamed: 'non-invention' patents. The only clear reason for applying for such patents, which will almost certainly be granted, is to give a superficial impression of innovation. The need to give an impression of innovation will be the greater, the higher the spend on R\&D - to show it is not being wasted. A superficial impression will be adequate, so long as the monitoring itself is superficial. On both counts the central SOEs have the strongest incentive to produce this output, the POEs the weakest. We thus propose Hypothesis 2:

H2a: The higher the level of government with a dominant shareholding, the higher the generation of non-invention patents.

H2b: For $100 \%$ domestic POEs, there will be fewer non-invention patents than for any category of SOE.

We now turn to the innovation output, or indicator, least easily gamed: forward citations of invention patents. Forward citations, excluding self- and domestic citations, reflect the quality of patents as nearly as is currently possible. High-quality patents are difficult to produce, and so we can assume that they are most produced where they are most valued: in enterprises where there is little or no -agency problem, or where the agents are well monitored. Enterprises in a position to buy or rent the innovations of others, have little reason to make the effort. We thus have Hypothesis 3a: 
H3a: The higher the level of government with a dominant shareholding, the fewer forward citations of invention patents.

For $\mathrm{H} 3 \mathrm{~b}$, however, we have two versions:

H3b (i): For $100 \%$ domestic POEs, there will be more forward citations than for any category of SOE.

This is based on the more moderate agency problem faced by (Chinese) POEs.

H3b (ii): For 100\% domestic POEs, there will be fewer forward citations than for municipal SOEs.

This is based on the better availability of finance to municipal SOEs.

In fact we have another measure of innovation which is not likely to be gamed, an indicator of the quality of innovation: the proportion of patents in active use. We can use essentially the same reasoning as with forward citations, except that keeping a patent in active use, unlike producing highly-cited inventions, is not expensive, so that POEs excel, and we can follow $\mathrm{H} 3 \mathrm{~b}(\mathrm{i})$ :

H4a: The lower the level of state government with a dominant shareholding, the higher the proportion of patents that will be in active use either in firms' own new products/processes or licensed out.

H4b: A higher proportion of patents will be in active use, in POEs than in any category of SOE. We summarize our hypotheses in figure 1.

Figure 1 Summary of Hypotheses H1-H4 
Resources can be wasted

\begin{tabular}{|l|l|}
\hline \multicolumn{2}{|c|}{ R\&D/turnover } \\
SOE & $\begin{array}{l}\text { Central } \\
\text { Super-municipal } \\
\text { Provincial } \\
\text { Municipal }\end{array}$ \\
$100 \%$ POE & H1 \\
\hline
\end{tabular}

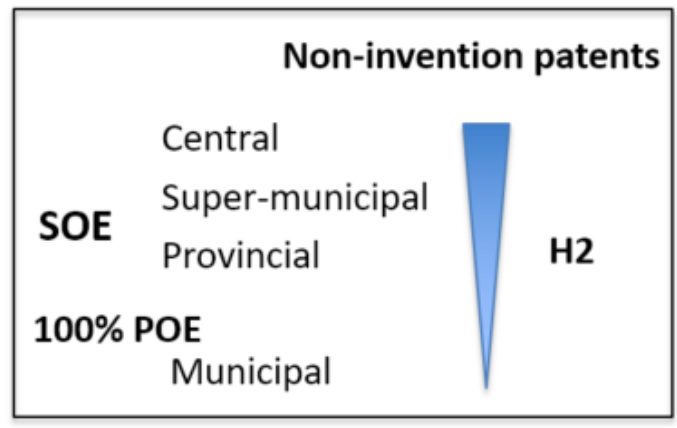

\section{Corporate governance is important}

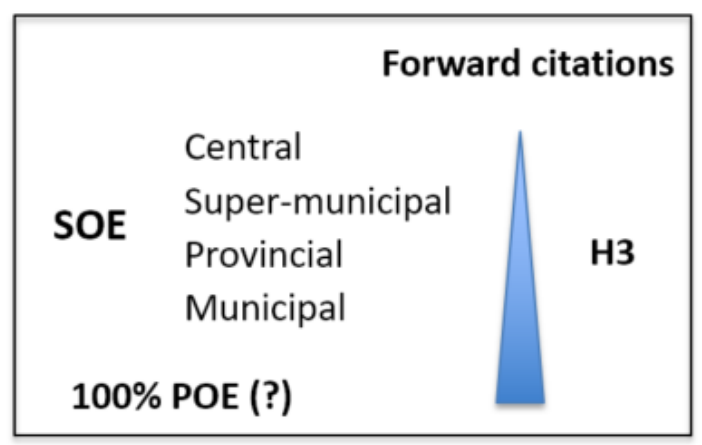

\begin{tabular}{|l|l|}
\hline \multicolumn{2}{|c|}{$\begin{array}{c}\text { Proportion of patents } \\
\text { in active use }\end{array}$} \\
SOE & $\begin{array}{l}\text { Central } \\
\text { Super-municipal } \\
\text { Provincial } \\
\text { Municipal }\end{array}$ \\
$100 \%$ POE
\end{tabular}

\section{Research methods}

The selection of the solar PV industry

To test our hypotheses, the research method needs to satisfy the following conditions. First, the industry studied must comprise both SOEs and POEs and display different levels of state ownership for the SOEs. Second, the industry should be regarded by government as strategic, and show a rich context of policies and subsidies. Third, the industry should show strong evidence of innovation. The Chinese solar photovoltaic industry fulfills these conditions. First, it presents a variety of ownership types including POEs, and SOEs owned by four different levels of government: central, super-municipal, provincial and municipal. Second, solar PV has been 
identified as one of the Strategic and Emerging Industries and the Chinese government has spent heavily on science and technology R\&D in these industries (STC, 2014). Third, China's solar PV has been successful in international competition, with seven of the global top ten cell manufacturers and eight of the top ten module manufacturers (PV-Tech, 2018). In our case, solar $\mathrm{PV}$ is set to be a major component of the energy mix in China and globally, and a technological field in which the Chinese government wants its firms to succeed. Moreover as one interviewee stated: "Solar [PV] is strategic as any industry for China... it is about energy independence, especially to a country with fast rising energy consumption" (Dow Corning, 2012). Solar PV thus gives us a particularly accurate means to assess the combined effect of institutional supports and agency mechanisms on firms' innovation performance.

\section{Research design}

This study adopted a mixed research method approach and was organized in three stages over a six-year period. During Stage 1 (2010-13), 58 semi-structured interviews were conducted on managerial decision-making of firms around R\&D investment relating to solar PV technologies, to Chinese innovation policies and to the domestic and international IP legal framework. Interviews in China were carried out in Beijing, Shanghai, Chengdu, and Jiangsu, four major locations where Chinese solar PV companies are based. Interviews were also carried out, by phone or in person, in six countries outside China (UK, Netherlands, Belgium, Switzerland, Germany and the US). These interviews combined with literature review to yield hypotheses for testing in Stage 2.

Stage 2 took place between 2014 to early 2016 during which a panel dataset was constructed, with its main focus on patent-related data. This began with a search for a full list of 
all Chinese solar PV firms. We searched the ENF list (http://www.enfsolar.com/) and the Directory of Photonics Industry (URL: http://www.coema.org.cn/news/article/74/) for five sectors: production equipment, solar components, materials, modules and apparatus. This search provided a total of 5127 Chinese firms. We triangulated these two lists against China Photovoltaic Industry Association (http://www.chinapv.org.cn/) as a third source. Our research scope is the most innovative firms in the Chinese solar PV industry, defined as having at least one invention count, because they constitute the main driving force of industry development. We then used the list of 5,127 firms to search through SIPO (State Intellectual Property Office) for each firm, its total invention patent counts, and non-invention (utility and design) patent counts. We found 468 firms with at least one invention patent. These 468 firms were then used for stage 3 of data collection.

In stage 3, mid-2016, a survey to these 468 was conducted in order to gather data on patents in active use, shareholding, $\mathrm{R} \& \mathrm{D}$, and other information such as size, age, location and agglomeration. For each company we required two returned survey questionnaires for data triangulation, which also allowed follow-up telephone calls to verify inconsistent information. We received complete survey questionnaires for 316 firms with a 67.5 percent response rate. Among 316 firms there are 69 which are either fully or majority owned by the state, and 47 wholly domestically privately owned. For this study, we focus on these 69 SOEs and 47 POEs. Next, we detail the variables used in this study.

Our panel data consists of four categories: patent-related, shareholding-related, R\&D expenses, and other information for control (age, size, subsidiary or not, location, listed or not, agglomeration). These data are available from 1999 to 2015. 


\subsection{Variables:}

Patent-related variables

Non-invention patent counts (collected in stage 2). We searched SIPO for each firm's noninvention patent counts. For this study, we took patents granted, not applied for). ${ }^{1}$

Forward citations of patents (collected in stage 2): We counted firms' forward citations of invention patents. We excluded firm's self-citations and domestic citations to avoid upward biases (Boeing and Mueller, 2019). Since forward citations were not at that time available from SIPO, the data was provided by incoPat (www.incopat.com), one of the largest patent platforms in China.

Patent in active use (collected in stage 3 through the survey): for each firm we first obtained patent information (including application number and name) from SIPO. In the survey we asked, for each firm and for each patent: 1) the number of licenses which had been issued based on this patent, and the year the license had been issued; 2) the number of new products/processes that had utilized the patent and the year new product/process had used the patent. The purpose of these detailed questions was to verify that the patent really was in active use or licensed out, rather than the payment to the awarding office being made just for show. The variable generated was binary: in active use or licensed out/not in active use or licensed out. Based on this variable we generated a second variable proportion of patent in active use over total number of patents. The second variable was used in our regression.

${ }^{1}$ OECD recommends the use of application counts to indicate firm's inventive performance ( OECD (2009) OECD Patent Statistics Manual.) We prefer to use grants because the success rate of Chinese invention patent applications is very low. In 2015, of 27.99 million applications only 3.59 million were granted, giving a $12.8 \%$ success rate (SIPO 2015). 
Shareholding-related variables (through survey)

We collected percentages of each firm held respectively by central state, provincial state, municipal state, super-municipal state, by foreign and by domestic private owners. This data was used to generate five categorical variables: majority or 100 percent state-owned (MASOE) with central, super-municipal, provincial and municipal state being largest shareholder respectively, and 100 percent domestic private. Restricting the fifth category to 100 percent domestically privately-owned enterprises simplified the corporate governance and finance assumptions which could be made about it.

$\mathrm{R} \& \mathrm{D}$ and other variables (through survey)

$R \& D$ budget was used. Familiar control variables are firm age, size (employee numbers), subsidiary (whether or not the firm was a subsidiary of a parent firm), whether listed (if it was listed on Chinese or foreign stock market), and location (coastal or inland area). In order to control the impact of foreign and domestic private shareholding (if any) on 69 SOEs' patent outcomes, foreign and domestic private share percentages in these 69 SOEs are also used as control variables. We also constructed an agglomeration rating to take into account any possible firm clustering effect, defined as the proximity of the focal firm to other firms (Tan, 2006). For each firm in the sample, the location (by city) of its headquarters was recorded. We then obtained the number of firms in the sample located within each city. Next, each firm was assigned a number showing its "agglomeration rating", i.e. the number of patenting firms in our sample within 100 miles.

\subsection{Models}


H1: The two hypotheses were tested by one-way ANOVA to determine if R\&D intensity was significantly different among four levels of SOEs, and higher in SOEs than POEs.

H2-H3: it is important to recognize input-output time-lags in R\&D. Leydesdorff and Wagner (2009) find that a two-year time lag between input and output is appropriate for highly aggregated data, while Prodan (2005) showed that a 1 to 3-year time-lag between input and output gives solid "explained variance in technology output". In approaching the relationship between the variables, we first lag the dependent variable by two years on $R \& D$, and by a further year on ownership variables. For control variables we lagged firm size, whether listed, foreign shareholding percentage, and domestic private shareholding percentage by three years.

In order to test the hypotheses, the following reduced-form equation is specified:

$\mathrm{Y}_{i t}=\alpha+\beta x_{i t-3}+u_{i t}+\alpha_{i}+\varepsilon_{i, t}$

where $i$ indexes firm id and $t$ ranges from 1999 to 2015. Dependent Variables are: H2 noninvention patent counts; H3 forward citation counts; H4 proportion of patents in active use or licensed out. The independent variables $x$ are dummies, denoting five shareholding categories: MASOE central, MASOE super-municipal, MASOE provincial, MASOE municipal, and 100 percent POE. $\mathrm{u}_{\mathrm{it}}$ captures control variables including firm age, size, if it is listed, if it is a subsidiary, location, agglomeration, foreign and domestic private shareholding in SOEs. Fixed effects $\left(\alpha_{i}\right)$ are introduced to capture unobservable firm-specific heterogeneity. All the residual variation is captured by the error term $\left(\varepsilon_{i, t}\right)$.

We first tested for overdispersion, and found that the variance (22.544) of non-invention patent counts was 9 times larger than the mean (2.518). We then used a conditional fixed-effects negative binomial model to estimate the reduced-form equation. The negative binomial has been 
suggested for estimating the number of occurrences of event counts (Cameron and Trivedi, 1998). In this study, an event count is the number of forward citation counts deposited at SIPO. In total, a panel of 116 firms (69 SOEs, 47 POEs) and 17 years observations (1999-2015) are available.

H4 was tested by using Tobit type 1 model. This is because of 789 observations 252 were zero. Furthermore, a Wald test was used to determine equality of coefficients for $\mathrm{H} 2-\mathrm{H}$.

\section{Analysis}

\subsection{Detailed findings}

Table 1 presents descriptive statistics of variables. 14.2 percent of the observations show predominantly central state ownership, 13.4 percent by 'super-municipal', 15.4 percent by provincial, 27.6 percent by municipal; and 29.4 percent have 100 percent domestic private ownership. The average count for non-invention patents is 2.518 , that for forward citations of invention patents is 0.443 and for proportion of patents in active use is 0.028 . The average age of firms is 15.567 years and the size of the firm ranges from 2.127 (logarithm value of employee numbers) to 4.284 with an average size of 3.737 .

Table 1 Descriptive statistics of explanatory variables (1999-2015)

\begin{tabular}{|c|c|c|c|c|c|}
\hline Variable & Obs. & Mean & SD & Min & Max \\
\hline State central & 490 & 0.442 & 1.253 & 0 & 1 \\
\hline State super municipal & 460 & 0.357 & 1.728 & 0 & 1 \\
\hline State provincial & 530 & 0.417 & 1.912 & 0 & 1 \\
\hline State municipal & 953 & 0.376 & 1.865 & 0 & 1 \\
\hline $100 \%$ domestic private & 1012 & 1 & 0 & 1 & 1 \\
\hline Non-invention patent counts & 1445 & 2.518 & 3.652 & 0 & 17 \\
\hline Forward citation counts & 639 & 0.443 & 1.310 & 0 & 13 \\
\hline $\begin{array}{l}\text { Proportion of patents in active } \\
\text { use }\end{array}$ & 1001 & 0.280 & 0.222 & 0 & 1 \\
\hline
\end{tabular}




\begin{tabular}{|c|c|c|c|c|c|}
\hline Age & 1173 & 15.567 & 10.902 & 6 & 57 \\
\hline Size $(\log )$ & 912 & 3.737 & 3.516 & 2.127 & 4.284 \\
\hline Subsidiary & 1652 & 0.292 & 0.455 & 0 & 1 \\
\hline Location & 1679 & 0.336 & 0.501 & 0 & 1 \\
\hline Listed & 1173 & 0.0775 & 0.268 & 0 & 1 \\
\hline Agglomeration & 1173 & 19.962 & 17.716 & 1 & 56 \\
\hline Foreign percentage & 489 & 4.886 & 7.335 & 0 & 25.7 \\
\hline Domestic private percentage & 631 & 11.046 & 10.962 & 0 & 24.6 \\
\hline
\end{tabular}

Table 2 presents variable correlations. Correlations between variables indicate that municipal state ownership has higher coefficients than central in terms of forward citations and proportion of patents in active use. POEs have the highest coefficient in proportion of patents in active use. 
Table 2 variable correlations

\begin{tabular}{|c|c|c|c|c|c|c|c|c|c|c|c|c|c|c|c|c|}
\hline & 1 & 2 & 3 & 4 & 5 & 6 & 7 & 8 & 9 & 10 & 11 & 12 & 13 & 14 & 15 & 16 \\
\hline 1. State central & 1 & & & & & & & & & & & & & & & \\
\hline 2. State super municipal & $\begin{array}{c}0.138 \\
(0.211)\end{array}$ & 1 & & & & & & & & & & & & & & \\
\hline 3. Provincial & $\begin{array}{c}0.106 \\
(0.273)\end{array}$ & $\begin{array}{c}0.114 \\
(0.252)\end{array}$ & 1 & & & & & & & & & & & & & \\
\hline 4. State municipal & $\begin{array}{c}0.131 \\
(0.217)\end{array}$ & $\begin{array}{c}0.092 \\
(0.384)\end{array}$ & $\begin{array}{c}0.146 \\
(0.176)\end{array}$ & 1 & & & & & & & & & & & & \\
\hline 5. $100 \%$ domestic private & $\begin{array}{c}0.056 \\
(0.421)\end{array}$ & $\begin{array}{c}0.029 \\
(0.576)\end{array}$ & $\begin{array}{c}0.112 \\
(0.249)\end{array}$ & $\begin{array}{c}0.158 \\
(0.145)\end{array}$ & 1 & & & & & & & & & & & \\
\hline $\begin{array}{l}\text { 6. Non-invention patent } \\
\text { counts }\end{array}$ & $\begin{array}{l}0.445^{* * * *} \\
(0.000)\end{array}$ & $\begin{array}{l}0.396^{* * * *} \\
(0.000)\end{array}$ & $\begin{array}{l}0.094^{+} \\
(0.072)\end{array}$ & $\begin{array}{c}0.032 \\
(0.578)\end{array}$ & $\begin{array}{c}0.025 \\
(0.634)\end{array}$ & 1 & & & & & & & & & & \\
\hline 7. Forward citation counts & $\begin{array}{c}0.135 \\
(0.273)\end{array}$ & $\begin{array}{c}0.190 \\
(0.106)\end{array}$ & $\begin{array}{l}0.328^{* *} \\
(0.007)\end{array}$ & $\begin{array}{c}0.417^{* * *} \\
(0.000)\end{array}$ & $\begin{array}{l}0.315^{* *} \\
(0.009)\end{array}$ & $\begin{array}{r}-0.174 \\
(0.163)\end{array}$ & 1 & & & & & & & & & \\
\hline $\begin{array}{l}\text { 8. Proportion of patents in } \\
\text { active use }\end{array}$ & $\begin{array}{c}0.107 \\
(0.271)\end{array}$ & $\begin{array}{c}0.128 \\
(0.203)\end{array}$ & $\begin{array}{l}0.321^{* *} \\
(0.009)\end{array}$ & $\begin{array}{c}0.372^{* * *} \\
(0.000)\end{array}$ & $\begin{array}{l}0.466^{* * *} \\
(0.000)\end{array}$ & $\begin{array}{l}-0.148 \\
(0.182)\end{array}$ & $\begin{array}{c}0.165 \\
(0.134)\end{array}$ & 1 & & & & & & & & \\
\hline 9. Location & $\begin{array}{c}0.175 \\
(0.123)\end{array}$ & $\begin{array}{c}0.075 \\
(0.402)\end{array}$ & $\begin{array}{c}0.015 \\
(0.761)\end{array}$ & $\begin{array}{l}0.109^{+} \\
(0.092)\end{array}$ & $\begin{array}{c}0.031 \\
(0.577)\end{array}$ & $\begin{array}{c}0.091 \\
(0.384)\end{array}$ & $\begin{array}{l}-0.071 \\
(0.294)\end{array}$ & $\begin{array}{c}0.012 \\
(0.743)\end{array}$ & 1 & & & & & & & \\
\hline 10. Age & $\begin{array}{l}0.357^{* *} \\
(0.005)\end{array}$ & $\begin{array}{l}0.262^{*} \\
(0.036)\end{array}$ & $\begin{array}{c}0.141 \\
(0.209)\end{array}$ & $\begin{array}{c}0.098 \\
(0.262)\end{array}$ & $\begin{array}{l}-0.161 \\
(0.140)\end{array}$ & $\begin{array}{c}0.103 \\
(0.355)\end{array}$ & $\begin{array}{c}0.173 \\
(0.125)\end{array}$ & $\begin{array}{l}-0.112 \\
(0.254)\end{array}$ & $\begin{array}{c}0.144 \\
(0.212)\end{array}$ & 1 & & & & & & \\
\hline 11. Size & $\begin{array}{l}0.212^{* *} \\
(0.009)\end{array}$ & $\begin{array}{c}0.187 \\
(0.113)\end{array}$ & $\begin{array}{c}0.152 \\
(0.184)\end{array}$ & $\begin{array}{c}0.127 \\
(0.180)\end{array}$ & $\begin{array}{c}0.065 \\
(0.421)\end{array}$ & $\begin{array}{l}-0.008 \\
(0.689)\end{array}$ & $\begin{array}{c}0.018 \\
(0.713)\end{array}$ & $\begin{array}{c}0.014 \\
(0.692)\end{array}$ & $\begin{array}{c}0.033 \\
(0.687)\end{array}$ & $\begin{array}{l}0.255 \\
(0.30)\end{array}$ & 1 & & & & & \\
\hline 12. Subsidiary & $\begin{array}{c}0.044 \\
(0.105)\end{array}$ & $\begin{array}{c}0.031 \\
(0.254)\end{array}$ & $\begin{array}{l}0.066^{+} \\
(0.057)\end{array}$ & $\begin{array}{l}0.075^{+} \\
(0.052)\end{array}$ & $\begin{array}{l}-0.013 \\
(0.623)\end{array}$ & $\begin{array}{c}0.128 \\
(0.021)\end{array}$ & $\begin{array}{c}0.082 \\
(0.119)\end{array}$ & $\begin{array}{l}-0.035 \\
(0.157)\end{array}$ & $\begin{array}{l}-0.117 \\
(0.139)\end{array}$ & $\begin{array}{c}0.021 \\
(0.276)\end{array}$ & $\begin{array}{c}0.047 \\
(0.381)\end{array}$ & 1 & & & & \\
\hline 13. Listed & $\begin{array}{c}0.058 \\
(0.421)\end{array}$ & $\begin{array}{c}0.043 \\
(0.425)\end{array}$ & $\begin{array}{c}0.143 \\
(0.207)\end{array}$ & $\begin{array}{c}0.158 \\
(0.140)\end{array}$ & $\begin{array}{l}0.187^{+} \\
(0.092)\end{array}$ & $\begin{array}{l}-0.162 \\
(0.113)\end{array}$ & $\begin{array}{c}0.135 \\
(0.219)\end{array}$ & $\begin{array}{c}0.178 \\
(0.120)\end{array}$ & $\begin{array}{c}0.088 \\
(0.291)\end{array}$ & $\begin{array}{l}0.249^{*} \\
(0.038)\end{array}$ & $\begin{array}{l}0.313^{* *} \\
(0.007)\end{array}$ & $\begin{array}{c}0.073 \\
(0.262)\end{array}$ & 1 & & & \\
\hline 14. Agglomeration & $\begin{array}{c}0.074 \\
(0.402)\end{array}$ & $\begin{array}{c}0.109 \\
(0.272)\end{array}$ & $\begin{array}{c}0.015 \\
(0.738)\end{array}$ & $\begin{array}{c}0.166 \\
(0.137)\end{array}$ & $\begin{array}{c}0.072 \\
(0.401)\end{array}$ & $\begin{array}{c}0.134 \\
(0.145)\end{array}$ & $\begin{array}{l}-0.077 \\
(0.398)\end{array}$ & $\begin{array}{l}-0.027 \\
(0.608)\end{array}$ & $\begin{array}{c}0.173 \\
(0.124)\end{array}$ & $\begin{array}{l}-0.110 \\
(0.254)\end{array}$ & $\begin{array}{r}0.124 \\
(0.276)\end{array}$ & $\begin{array}{l}0.112 \\
(0.231)\end{array}$ & $\begin{array}{l}-0.115 \\
(0.252)\end{array}$ & 1 & & \\
\hline 15.Foreign percentage & $\begin{array}{c}0.112 \\
(0.252)\end{array}$ & $\begin{array}{c}0.134 \\
(0.216)\end{array}$ & $\begin{array}{c}0.168 \\
(0.140)\end{array}$ & $\begin{array}{c}0.192 \\
(0.087)\end{array}$ & $\begin{array}{c}0.011 \\
(0.743)\end{array}$ & $\begin{array}{r}-0.124 \\
(0.142)\end{array}$ & $\begin{array}{c}0.026 \\
(0.742)\end{array}$ & $\begin{array}{c}0.197 \\
(0.062)\end{array}$ & $\begin{array}{c}0.115 \\
(0.254)\end{array}$ & $\begin{array}{c}0.045 \\
(0.429)\end{array}$ & $\begin{array}{l}0.287^{* *} \\
(0.003)\end{array}$ & $\begin{array}{c}0.061 \\
(0.267)\end{array}$ & $\begin{array}{c}0.144 \\
(0.207)\end{array}$ & $\begin{array}{c}0.087 \\
(0.388)\end{array}$ & 1 & \\
\hline $\begin{array}{l}\text { 16. Domestic private } \\
\text { percentage }\end{array}$ & $\begin{array}{c}0.098 \\
(0.386)\end{array}$ & $\begin{array}{c}0.072 \\
(0.401)\end{array}$ & $\begin{array}{c}0.135 \\
(0.213)\end{array}$ & $\begin{array}{c}0.142 \\
(0.205)\end{array}$ & $\begin{array}{c}0.096 \\
(0.264)\end{array}$ & $\begin{array}{l}-0.148 \\
(0.124)\end{array}$ & $\begin{array}{c}0.107 \\
(0.242)\end{array}$ & $\begin{array}{c}0.131 \\
(0.211)\end{array}$ & $\begin{array}{c}0.078 \\
(0.400)\end{array}$ & $\begin{array}{l}-0.067 \\
(0.414)\end{array}$ & $\begin{array}{l}-0.183^{+} \\
(0.082)\end{array}$ & $\begin{array}{c}0.051 \\
(0.276)\end{array}$ & $\begin{array}{c}0.078 \\
(0.397)\end{array}$ & $\begin{array}{c}0.044 \\
(0.426)\end{array}$ & $\begin{array}{c}0.161 \\
(0.139)\end{array}$ & 1 \\
\hline
\end{tabular}

${ }^{+} p<0.1, * p<0.05 ; * * p<0.01 ; * * * p<0.001$ 
H1a implies that central SOEs have higher R\&D intensity than municipal SOEs. H1b predicts that even municipal SOEs have higher intensity than POEs. A Tukey post-hoc test reveals that the rate of $R \& D$ spend to turnover is significantly higher for central than municipal SOEs $(2.122, p=.000)$. There is also a significant difference between municipal SOEs and POEs $(1.340, p=.000)$. See table III. Thus, Hla and H1b are supported (See Table 3).

Table 3 One way ANOVA test of R\&D/turnover between groups

\begin{tabular}{|c|c|c|c|c|c|c|}
\hline Ownership types & \multicolumn{2}{|c|}{$\begin{array}{c}\text { Mean (\% of } \\
\text { R\&D/turnover) }\end{array}$} & \multicolumn{2}{|c|}{ Standard Deviation } & \multicolumn{2}{|c|}{ Frequencies } \\
\hline Central SOEs & \multicolumn{2}{|c|}{5.27} & \multicolumn{2}{|c|}{0.94} & \multicolumn{2}{|c|}{814} \\
\hline Super-municipal SOEs & \multicolumn{2}{|c|}{5.04} & \multicolumn{2}{|c|}{0.88} & \multicolumn{2}{|c|}{764} \\
\hline Provincial SOEs & \multicolumn{2}{|c|}{3.33} & \multicolumn{2}{|c|}{0.83} & \multicolumn{2}{|c|}{880} \\
\hline Municipal SOEs & \multicolumn{2}{|c|}{3.15} & \multicolumn{2}{|c|}{0.93} & \multicolumn{2}{|c|}{1582} \\
\hline POEs & \multicolumn{2}{|c|}{1.81} & \multicolumn{2}{|c|}{0.91} & \multicolumn{2}{|c|}{1684} \\
\hline \multicolumn{7}{|c|}{ Tukey post-hoc test } \\
\hline \multirow{2}{*}{ R\&D/turnover (\%) } & \multirow{2}{*}{ Contrast } & \multirow{2}{*}{ Std. Err. } & \multicolumn{2}{|c|}{ Tukey } & \multicolumn{2}{|c|}{ Tukey } \\
\hline & & & $\mathrm{t}$ & $\mathrm{P}>|\mathrm{t}|$ & $95 \% \mathrm{c}$ & terval \\
\hline $\begin{array}{l}\text { Central SOEs vs Super- } \\
\text { municipal }\end{array}$ & 0.231 & 0.135 & 2.38 & 0.122 & -0.034 & 0.496 \\
\hline Central SOEs vs Provincial & 1.944 & 0.136 & 19.93 & 0.000 & 1.677 & 2.211 \\
\hline Central SOEs vs Municipal & 2.122 & 0.132 & 22.37 & 0.000 & 1.863 & 2.381 \\
\hline Municipal SOEs vs POEs & 1.340 & 0.104 & 17.96 & 0.000 & 1.136 & 1.544 \\
\hline
\end{tabular}

Table 4 presents beta coefficients and their exponents: the important figures are not the individual coefficients but the differences between them, which are subjected to a Wald test for 
significance (Table 5). Among the SOEs, the largest differences are naturally between the topcentral SOEs, and the bottom - municipal SOEs, and it is these differences that we focus on.

With H2a we predicted that central SOEs would be more inclined to waste their (ample) resources on non-invention patents than any other type of SOE, and indeed municipal ownership underperforms central state ownership for non-invention patents by $\exp (0.610)$ against $\exp (2.052)$ (see Table 4), with $\mathrm{p}=0.000$ (see Table 5), with corresponding values for provincial and supermunicipal ownership. Thus H2a is strongly supported. Likewise, we predicted that POEs would be the least wasteful of all, and indeed municipal ownership narrowly outperforms private ownership by $\exp (0.610)$ against $\exp (0.336)$ (see Table 4), with $\mathrm{p}=0.049$ (see Table 5). Thus $H 2 b$ is weakly supported. With $\mathrm{H} 3$ we dealt, on the other hand, with the most valuable expression of patents, forward citations: our predictions were that un-innovative central SOEs would underperform here in spite of better access to finance. So they did: municipal ownership outperforms central state ownership for forward citations by $\exp (1.843)$ against $\exp (0.179)$ (see Table 4), with $\mathrm{p}=0.000$ (see Table 5), with corresponding values for provincial and supermunicipal ownership. Thus H3a is strongly supported. The effect of better access to financial resources does seem to play a role, however, in the fact that municipal ownership narrowly outperforms private ownership in forward citations (exp (1.843) against $\exp (1.748)$ (see table 4) with $\mathrm{p}=0.046$ for Wald test (see Table V). Thus it is $H 3 b$ (ii) which is (weakly) supported.

Our results also support $\mathrm{H} 4 \mathrm{a}$ and $\mathrm{H} 4 \mathrm{~b}$. Municipally-owned firms are more active in using patents in firms' own new products/processes or licensing out in exchange for a share of rents (0.215) than centrally-owned SOEs (-0.159) see Table 4), with $\mathrm{p}=0.000$ (see Table 5). Thus $H 4 a$ 
is strongly supported. POEs have a higher rate (0.265) (see Table 4) than for any category of SOEs - the difference from municipal SOEs gives only $\mathrm{p}=0.039$, however (see Table 5). Thus H4b is weakly supported. 
Table 4 Estimated coefficients of the negative binomial fixed effects models of H2 to H4

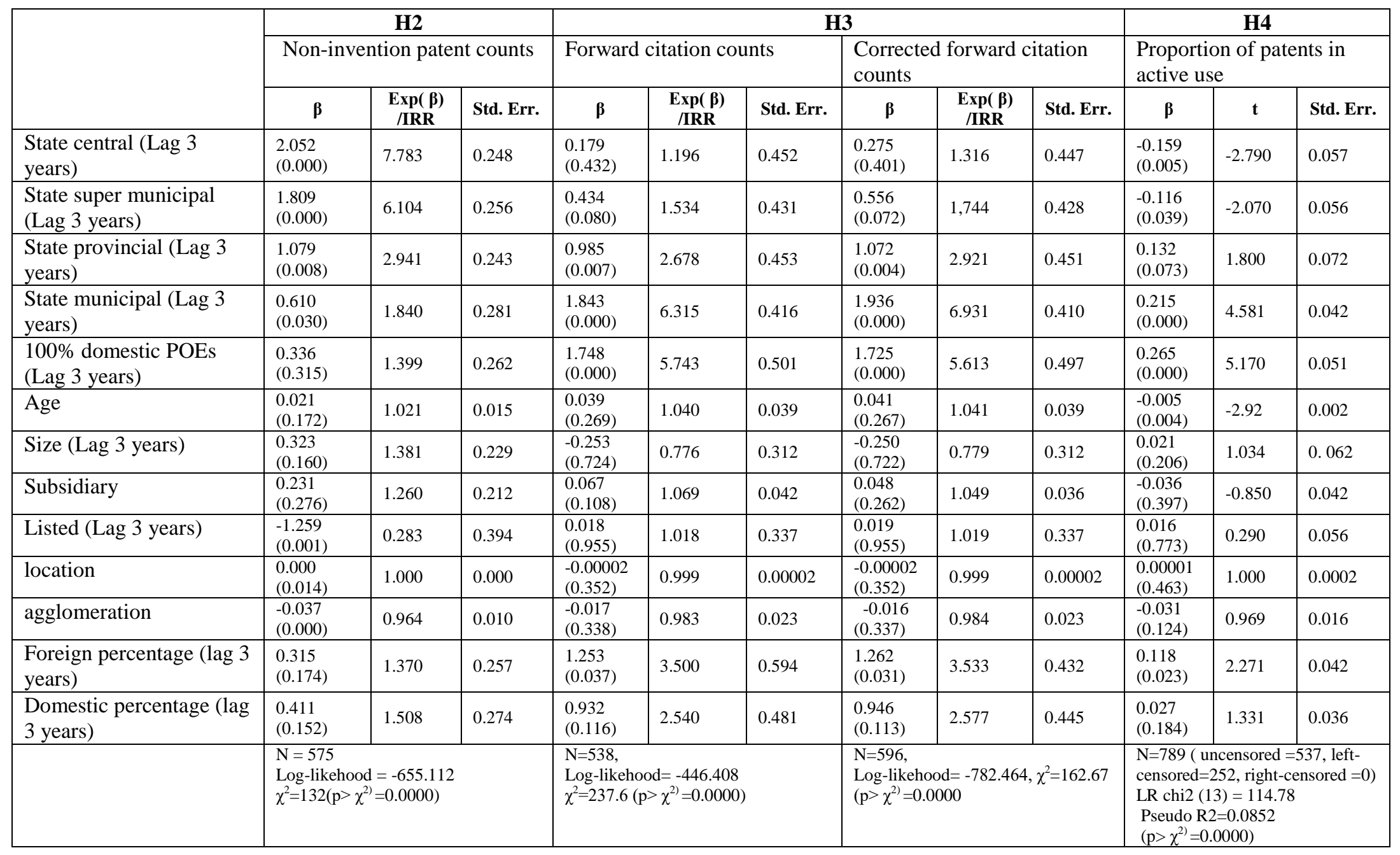


Table 5 Wald test of the equality of coefficients

\begin{tabular}{|c|c|c|c|}
\hline & $\begin{array}{c}\mathrm{H} 2 \\
\text { Non-invention patent counts } \\
\end{array}$ & $\begin{array}{c}\mathrm{H3} \\
\text { Forward citations } \\
\end{array}$ & $\begin{array}{c}\mathrm{H4} \\
\text { Proportion of Patents in active use }\end{array}$ \\
\hline Supermunicipal vs Central & $\begin{array}{l}\text { Chi2 }(1)=0.34 \\
\text { Prob }>\text { chi2 }=0.562\end{array}$ & $\begin{array}{l}\text { Chi2 }(1)=0.53 \\
\text { Prob }>\text { chi } 2=0.435\end{array}$ & $\begin{array}{l}\text { Chi2 }(1)=0.21 \\
\text { Prob }>\text { chi2 }=0.666\end{array}$ \\
\hline Municipal vs Provincial & $\begin{array}{l}\text { Chi2 }(1)=7.48 \\
\text { Prob }>\text { chi } 2=0.009\end{array}$ & $\begin{array}{l}\text { Chi2 }(1)=6.68 \\
\text { Prob }>\text { chi2 }=0.009\end{array}$ & $\begin{array}{l}\text { Chi2 }(1)=5.11 \\
\text { Prob }>\text { chi2 }=0.014\end{array}$ \\
\hline Municipal vs Central & $\begin{array}{l}\text { Chi2(1) }=26.35 \\
\text { Prob }>\text { chi2 }=0.000\end{array}$ & $\begin{array}{l}\text { Chi2 }(1)=15.98 \\
\text { Prob }>\text { chi2 }=0.000\end{array}$ & $\begin{array}{l}\text { Chi2(1) }=11.36 \\
\text { Prob }>\text { chi2 }=0.000\end{array}$ \\
\hline $100 \%$ Domestic POEs vs Municipal & $\begin{array}{l}\text { Chi } 2(1)=3.05 \\
\text { Prob }>\text { chi2 }=0.049\end{array}$ & $\begin{array}{l}\text { Chi } 2(1)=3.29 \\
\text { Prob }>\text { chi } 2=0.046\end{array}$ & $\begin{array}{l}\text { Chi } 2(1)=3.48 \\
\text { Prob }>\text { chi } 2=0.039\end{array}$ \\
\hline
\end{tabular}




\subsection{The test of model robustness}

1) Citation truncation bias: our citation data were recorded from 1999-2015. Bias in our citation counts exists as we will not be able to observe citations for patents granted during the later years of our sample. In order to test the effect of citation truncation bias, we modified Hall et al. (2000) citation lag distribution model which incorporates both the knowledge diffusion process $\left(\exp \left(\beta_{2} s\right)\right)$ and the obsolescence process $\left(\exp \left(-\beta_{1} s\right)\right)$ :

$$
D_{s}=\beta_{0} \exp \left(-\beta_{1} s\right)\left(1-\exp \left(\beta_{2} s\right)\right)
$$

Where $D_{s}$ is the count distribution; $s$ is the citation time lag for a patent issued at time $t$.

We then used the following formula to predict number of citations that go beyond 2015 and that cannot be observed from our data set.

$$
C_{t, s}=D_{s} E\left\{\sum_{J=0}^{10} C_{t, j} \mid \sum_{J=0}^{S} C_{t, j}=0\right\}
$$

Where $t$ is the patent grant year; $s$ is the citation time lag for a patent granted at time $t$, $s$ ranges from 0 to $10 ; \mathrm{S}$ is the first number of years that we observe 0 citations since a patent is granted.

We counted and calculated firms' forward citations of invention patents in a ten-year-period, based on the OECD (2009) suggestion that more than 80 percent of forward citations happen within this time period. To derive the estimated total (10 year) citations for a patent that is granted after 2006, we summed the observed citations and the predicted citations. These "corrected" citation counts were then tested in regressions to compare against the results from observation counts. We find both observed citations and corrected citations achieved similar 
results though the corrected citations have slightly improved coefficients. We present our corrected citation results in Table 4 .

2) Reverse causality: The assumption expressed in the hypotheses and the model is that the direction of causation runs from ownership to patenting. However, any correlation that is found could be the consequence of causation running the other way: e.g. a strong patent output leading to a lower level of state shareholding. In each direction of causation a clear time lag can be assumed. In the expected direction it is three years. In the "reverse" direction it seems unlikely to be less than two years. Thus, where the predicted effect of ownership at time $t$ is on patenting at time $\mathrm{t}+3$, the "reverse" possibility is that ownership at time $\mathrm{t}$ is affected by patenting at time $\mathrm{t}-2$ (and before). We tested this potential reverse effect. Results show non-significant coefficients of the predicted reverse direction. We also tested time lag for 3 and 4 years and obtained similar results. We therefore conclude that reverse causation has not been found in this study.

3) Time lag: in this study we assumed a 2 year lag on R\&D and a 3 year lag on ownership (Leydesdorff and Wagner 2009; Prodan, 2005). To test our assumptions we also ran regressions assuming a 1 year or a 3 year lag on $\mathrm{R} \& \mathrm{D}$, and a 2 year or a 4 year lag on ownership. We did not find as strong statistical significance. Therefore the original assumption of a 2 year lag on R\&D and a 3 year lag on ownership stands.

4) We understand that the quality of SIPO invention patents is more uneven than that of patents as awarded by the American USPTO for example. We re-tested H3 by using invention patent counts as the dependent variable. We achieved results consistent with forward citations and patent in active use.

\section{Discussion and Conclusion}


This paper examines the innovation performance of firms owned by different levels of government, comparing one level with another and with privately-owned firms. The agency theory is contextualised in a political-economic context to have a fuller understanding of the aims of the principals, the institutional support and key governance mechanisms that shape firms' innovation performance. In this study, the ultimate principal of SOEs is a political party whose aims include economic growth, innovation and technological progress. The Chinese NSI encourages innovation largely by providing funds for it - through direct subsidy of R\&D; through cheap loans; and through central SOEs' freedom to retain and recycle their profits. The central SOEs are the main beneficiaries of these arrangements, which was confirmed by our sample. Extant research such as Inoue et. al., (2013) and Li et al., 2017 have argued that government support like subsidies to R\&D and low-interest loans have a positive influence on firms' R\&D spending and innovation performance. Our research suggests that these institutional incentives and supports do have such an effect on inputs - R\&D - and nearly valueless outputs non-invention patents: in both, central SOEs lead. . That is the first empirical contribution of our paper, but it must be seen in the context of the second empirical contribution, which is not in accord with the literature cited: in spite of their institutional supports central SOEs produce the fewest forward citations and have the fewest patents in active use. It is the municipal SOEs which do best in spite of their relatively meagre funding; and the POEs' performance is similar, although still less well funded. So the innovation outputs of real value show a quite different and more surprising picture.

This second contribution is the more important because our finding is predicted and explained in this paper. We set out a triangle of comparison between three quite different power structures in 
mainland China: that which governs central state-owned enterprises; that which governs municipal SOEs; and that which governs privately owned enterprises. Our detailed analysis of Chinese agency structures show that in the Chinese system of 'fragmented authoritarianism' (Lieberthal, 2012) the central SOEs have become 'small kingdoms' (Brodsgaard 2012) which have a very high degree of autonomy. They are subject to market pressures, but with all kinds of protections and advantages. Further, to the extent that they are governed and monitored externally, the responsibility for doing so is divided among three government organs, making monitors less determined and more easily misled. When we looked at the most different category of SOEs, those owned by municipal government, the lowest level, we got a very different picture of agency structures. Municipal SOEs are less protected from market forces than central SOEs, and they are exposed to local party and state leaders who have an incentive to make a serious effort at monitoring, as a group. The agency chain is thus shorter and less complicated for local than central SOEs. Finally, POEs can have great information asymmetries and misalignments of incentives, but in Chinese POEs - in our sample at least - agency conflicts are moderated by small size, young age, and the founder remaining top manager. In other words, our POEs do not appear to have severe distortions in governance.

These three distinct governance types are all confronted within the Chinese solar pv industry with the need to innovate (in a broad sense). The granular, opaque,nature of innovation projects makes it difficult to govern and to monitor even the relatively incremental, technologyfollowing type which predominate in Chinese solar PV. What will be the future value of what is being learnt now? What is being learnt now? Top managers are in a good position to judge this. If they have incentives aligned with those of the principals they will be able and willing to maximise the value of learning. If they are Chinese POE top managers they will almost certainly 
be principals. If they are Chinese municipal SOE top managers they will may well have long tenure, which tends to align incentives. If they are Chinese central SOE top managers neither of these conditions applies. If (as in any SOE) the alignment of incentives is not complete, then the less the asymmetry of innovation the better. This requires monitoring by an individual or cohesive group within a simple agency chain - as appears to be common for Chinese municipal SOEs.

Our final contribution is that this paper identifies and uses valid and reliable measures of innovation in the Chinese (and developing) context. As we saw above, some studies, have praised the innovative output of Chinese central SOEs. The crucial measure which appears to show them as innovative is new product sales/total sales. This is a measure which is a valid indicator of innovation in advanced economies, because existing products reflect the global state of the art: new products must go beyond it. In a developing economy, however, a very wellfunded firm can introduce a succession of 'new' products which may be new to it and even to the economy, but not to the world, by buying or renting the technology from leading foreign firms. As we showed, forward citations of patents are more valid measures of innovation and harder to game.

We have thus set out to drill down into causes of successful governance of innovation in emerging economies. POEs with different ownership structures and with managers hired with short tenure, might do much worse than those which we examined. Even central SOEs might do better with long-tenured managers and experienced and cohesive monitors. Our conclusion for policy is therefore that causes matter more than categories. These implications are relevant not 
only to higher-technology industries in mainland China but also to other developing economies, particularly large ones.

This study is not free from limitations. We have described the solar photovoltaic industry as 'higher-technology'. It is high-tech in terms of its location in the semi-conductor sphere, but only medium-high in its own R\&D intensity. Solar PV firms' R\&D intensity is well below that which is associated with high-tech (over 10 percent) (Cheyney, 2014), and our sample's intensity is 3.71 percent. It may be that even higher-technology sectors, with higher R\&D intensity, make heavier demands on firms' financial resources - favouring well-funded SOEs.

\section{References:}

Aghion, P., Van Reenen J., Zingales L., (2013). 'Innovation and institutional ownership', American Economic Review 103(1), 277-304.

Aguilera, R., Filatotchev, I., Gospel H., Jackson, G., (2008). 'An organizational approach to comparative corporate governance: costs, contingencies, and complementarities', Organization Science 19(3), 475-492.

André, R., (2010). 'Assessing the accountability of government-sponsored enterprises and quangos'. Journal of Business Ethics, 97(2), 271-289.

Bergloef E 1997 Reforming corporate governance: redirecting the European agenda. Economic Policy 24 (April): 93-123.

Boeing, P., Mueller, E., Sandner, P., (2016). 'China's R\&D explosion - analyzing productivity effects across ownership types and over time', Research Policy, 45(1), 159-176.

Brodsgaard, K. E., (2012). 'Politics and business group formation in China: the party in control?' The China Quarterly, 211, 624-637. 
Cameron, A.C., and Trivedi, P.K., (1998). Regression analysis of count data. Cambridge, New York: Cambridge University Press.

Caselli, F. and Gennaioli, (2013) 'Dynastic management', Economic Inquiry 51 (1) 971-996.

Cheyney, T., (2014). 'Can Solar Companies Really Be Called 'High-tech'?' Renewable Energy World.

http://www.renewableenergyworld.com/articles/2014/12/can-solar-companies-really-becalled-high-tech.html

Choi, S.B., Lee, S.H., Williams, C., (2011). 'Ownership and firm innovation in a transition economy: evidence from China', Research Policy, 40 (3), 441-452.

Connelly, B., Hoskinsson, R., Thhanyi, L., Certo, S., (2010). 'Ownership as a form of corporate governance', Journal of Management Studies, 47(8), 1561- 1589.

Chung, J.H., (2000). Central Control and Local Discretion in China - Leadership and Implementation During Post-Mao Decollectivisation, Oxford: Oxford University Press.

Cull, R., Li, W., Sun, B., Xu, L.C., (2015). 'Government connections and financial constraints: evidence from a large representative sample of Chinese firms', Journal of Corporate Finance, $32,271-294$.

Cull, R., Xu, L., Yang, X., Zhou, L., Zhu, T., (2017). 'Market Facilitation by local government and firm efficiency: evidence from China', Journal of Corporate Finance, 42, 460-480.

Deng, X., Zhang, L., Leverentz, A., (2009). The dual system of land use policy and its related problems in contemporary China - China in an era of transition. Springer.

Deng, Z., Hofman, P.S., Newman, A., (2013). 'Ownership concentration and product innovation in Chinese private SMEs', Asia Pacific Journal of Management, 30(3), 717-734. 
DiMaggio, P. J., \& Powell, W. W., (1991). 'Introduction'. In W. W. Powell \& P. J. DiMaggio (ed..), The new institutionalism in organizational analysis pp. 1-38. Chicago: University of Chicago Press.

Eisenhardt, K., (1989). 'Agency Theory: An Assessment and Review', Academy of Management Review, 14 (1), 57-74.

Freeman, C., (1987). Technology Policy and Economic Performance: Lessons from Japan, London: Pinter.

Fuller, D.B., (2016). Paper Tigers, Hidden Dragons: Firms and the Political Economy of China's Technological Development. Oxford: Oxford University Press.

Godfrey, P. E., (2014). More than money: Five forms of capital to create wealth and eliminate poverty. Stanford, CA: Stanford University Press.

Guan, J.C., Yam, RCM. (2015). ‘Effects of government financial incentives on firm's innovation performance in China: evidences from Beijing in the 1990s'. Research Policy, 44(1), 273-282.

Hall, B.H., Jaffe, A., Trajtenberg, M., (2000). 'Market Value and Patent Citations: A First Look'. NBER Working Paper 7741, Washington, D.C.: National Bureau of Economic Research.

Hall, B.H. (2005). The financing of innovation, in Shane, S (ed.) Handbook of technology and innovation management, pp, 409-430, Oxford: Blackwell.

Inoue, C.F., Lazzarini, S.G., Musacchio, A., (2013). 'Leviathan as a minority shareholder: Firmlevel implications of state equity purchases', Academy of Management Journal, (56), 17751801.

Jensen, M.C., Meckling, W.H., (1976). 'Theory of the Firm: Managerial Behaviour, Agency Costs and Ownership Structure', Journal of Financial Economics, 3, 305-360. 
Leydesdorff, L., Wagner, C., (2009). 'Macro-level Indicators of the Relations between Research Funding and Research Output', Journal of Informetrics, 3(4), 353-362.

Li, J. Xia, J. E., Zajac, J., (2017). 'On the duality of political and economic stakeholder influence on firm innovation performance: theory and evidence from Chinese firms', Strategic Management Journal, 39 (1), 193-216.

Liu, J. Tylecote, A., (2009). 'Corporate governance and technological capability development: Three case studies in the Chinese Auto industry', Industry and Innovation, 16(4-5), 525-544.

Lu, F., Feng, K., (2004). Fazhan woguo zizhu zhishichanquan qichegongye de zhengce xuanze (In Chinese: The Policy Choice in Developing China's Proprietary Car Industry), Beijing: Beijing University Press.

Mathews, John A. (2002). Competitive Advantages of the Latecomer Firm: A Resource-Based Account of Industrial Catch-Up Strategies. Asia Pacific Journal of Management, 19, 467-488.

Minetti, R., Murro, P. and Paiella, M (2015). Ownership structure, governance and innovation, European Economic Review 80 165-193.

Mutlu, C.C., Essen, M., Peng, M.M., Saleh, S., Duran, P., (2018). Corporate governance in China: a meta-analysis, Journal of Managment Studies, 55(6), 943-979.

OECD, OECD Patent Statistics Manual, 2009

URL:http://www.oecd-ilibrary.org/science-and-technology/oecd-patent-statisticsmanual_9789264056442-en

Pisano, G.P., Teece, D.J., (2007). 'How to capture value from innovation: Shaping intellectual property and industry architecture', California Management Review, 50(1), 278-296. 
Poczter, S., (2016). 'Can monitoring improve the performance of state-owned firms?' Evidence from privatization in a large emerging market, Industrial and Corporate Change, 25(6), 903921.

Prodan, I. (2005). 'Influence of research and development expenditures on number of patent applications: selected case studies, in: OECD countries and central Europe, 1981-2001', Applied Econometrics and International Development, 5 (4),5-22.

Pache, A.-C., Santos, F., (2013). 'Inside the hybrid organization: Selective coupling as a response to competing institutional logics'. Academy of Management Journal, 56(4), 9721001.

Scott, W. R., (2014). Institutions and organizations: Ideas, interests, and identities. Thousand Oaks, CA: Sage Publications.

PV-Tech 2018 https://www.pv-tech.org/editors-blog/top-10-module-suppliers-in-2017

Qian, Y. (2002). 'How Reform Worked in China', William Davidson Institute Working Paper No 473, William Davidson Institute, University of Michigan.

Qiao, Y., Shen, J. (2017). The Cross-National Comparative Study of the Maintenance Time of Granted Patents in the Technical Field of Fixed Constructions in Different Countries, in: Qiao Y. (ed.), Maintenance Time and the Industry Development of Patents. Singapore: Springer,pp. 9-56.

Rajan, R and Zingales, L (2001) Financial systems, industrial structure and growth. Oxford Review of Economic Policy, 17 (4) 467-487.

Schivardi, F, and Schneider, M (2008) Strategic experimentation and disruptive technological change, Review of Economic Dynamics 11, 386-412. 
Schmid, T., Achleitner, A.K., Ampenberger, M., Kaserer, C., (2014) Family firms and R\&D behaviour: new evidence from a large-scale survey, Research Policy 43 (1), 233-244.

Shleifer, A., Vishny, R.W., (1986). 'Large Shareholders and Corporate Control', Journal of Political Economy, 94(3), 461-88.

State Council, (2010). 'Decision of the State Council on Accelerating the Fostering and Development of Strategic Emerging Industries' (in Chinese). http://www.gov.cn/zwgk/2010-10/18/content_1724848.htm

STC (2014). China Statistical Yearbook On Science and Technology. China Statistics Press.

Tan, J., (2006). 'Growth of industry clusters and innovation: Lessons from Beijing Zhongguancun Science Park', Journal of Business Venturing, 21(6), 827-850.

The Economist, January $21^{\text {st }}$ (2012), Special report: State capitalism, 1-18.

Wang, J., Guthrie, D., Xiao, Z., (2012). 'The rise of SASAC: asset management, ownership concentration, and firm performance in China's capital markets'. Management and Organization Review, 8(2), 253-281.

Williamson, O. E., (1975). Markets and hierarchies: Analysis and antitrust implications. New York: Free Press.

Xinhua News, (2017). The Chinese patent application is flooded with only $2 \%$ of the granted patents in active use. http://news.xinhuanet.com/finance/2017-04/04/c_1120747605.htm

Yu, F., Guo, Y., Le-Nguyen, K., Barners, S.J. Zhang, W., (2016). 'The impact of government subsidies and enterprises' R\&D investment: A panel data study from renewable energy in China', Energy Policy, 89, 106-113. 
Zhou, K.Z., Gao, G.Y., Zhao, H., (2017). 'State ownership and firm innovation in China: an integrated view of institutional and efficiency logics', Administrative Science Quarterly, 62(2), 375-404. 